\title{
Signalling mechanisms of long term facilitation of breathing with intermittent hypoxia Matthew E Pamenter ${ }^{1,2}$ and Frank L Powell ${ }^{1 *}$
}

\author{
Addresses: ${ }^{1}$ Physiology Division, Department of Medicine, University of California San Diego, La Jolla, CA 92092-0623, USA; ${ }^{2}$ Department of \\ Zoology, University of British Columbia, Vancouver, BC V6T 1Z4, Canada \\ *Corresponding author: Frank L Powell (fpowell@ucsd.edu) \\ FI000Prime Reports 2013, 5:23 (doi:10.12703/P5-23) \\ This is an open-access article distributed under the terms of the Creative Commons Attribution-Non Commercial License \\ (http://creativecommons.org/licenses/by-nc/3.0/legalcode), which permits unrestricted use, distribution, and reproduction in any medium, \\ provided the original work is properly cited. You may not use this work for commercial purposes. \\ The electronic version of this article is the complete one and can be found at: http://fl000.com/prime/reports/b/5/23
}

\begin{abstract}
Intermittent hypoxia causes long-term facilitation (LTF) of respiratory motor nerve activity and ventilation, which manifests as a persistent increase over the normoxic baseline for an hour or more after the acute hypoxic ventilatory response. LTF is likely involved in sleep apnea, but its exact role is uncertain. Previously, LTF was defined as a serotonergic mechanism, but new evidence shows that multiple signaling pathways can elicit LTF. This raises new questions about the interactions between signaling pathways in different time domains of the hypoxic ventilatory response, which can no longer be defined simply in terms of neurochemical mechanisms.
\end{abstract}

\section{Introduction}

During periods of systemic hypoxia (e.g. from lung disease or high altitude), the body's first line of defence is the hypoxic ventilatory response, a reflex increase in ventilation mediated by arterial chemoreceptors, primarily in the carotid bodies [1]. The hypoxic ventilatory response is a complex interplay between several distinct mechanisms whose net effect varies depending on the pattern and intensity of hypoxic exposure. Depending on the pattern of hypoxic stimulation, the hypoxic ventilatory response may change as a result of short-term effects that temporarily alter synaptic activity (e.g. increased neurotransmitter release) or long-term effects that alter the strength of chemical synapses of ventilatory control circuits (e.g. receptor modification or new protein synthesis). These changes result in either facilitation or depression of ventilation that lasts from seconds to years [2]. Since such mechanisms alter future ventilatory responses, they are examples of neuroplasticity in the ventilatory control system [3]. For example, a train of brief episodes of intermittent hypoxia results in LTF of ventilation, which manifests primarily as an increase in tidal volume that lasts for up to 90 minutes after the final stimulus $[2,4,5]$. Alternatively, chronic sustained hypoxia results in ventilatory acclimatization to hypoxia, which is an increase in ventilation (mainly breathing frequency) that lasts for days to weeks following removal of the hypoxic stimulus [2]. Different time domains of the hypoxic ventilatory response may be involved in different diseases with hypoxemia, e.g. LTF in sleep apnea with intermittent hypoxia and ventilatory acclimatization to hypoxia in chronic obstructive pulmonary disease with chronic hypoxemia.

In 1998 [2], the different time domains of the hypoxic ventilatory response were defined and distinguished on the basis of the following: (1) the pattern and intensity of hypoxic exposure; (2) the time course of the response (seconds to years); (3) the effects of this stimuli on the various physiological components of the hypoxic ventilatory response (e.g. breathing frequency and tidal volume); (4) whether these effects result in an increase or decrease in ventilation; and (5) the neurochemicals necessary for the manifestation of these responses [2]. Recently, considerable progress has been made in the study of LTF in particular, and it has become clear that multiple signaling pathways can cause the same change in ventilation. It can be expected that specific mechanisms will be activated 
and extinguished at different times depending on species, experimental preparations and individuals. Thus, defining a given time domain of a ventilatory response in terms of a neurochemical or signaling pathway can be ambiguous when trying to compare results between different studies. To resolve this dilemma, we now propose to define the different time domains of the hypoxic ventilatory response as physiological responses to a given hypoxic stimulus, which may have multiple underlying molecular and cellular mechanisms. A corollary is that a specific mechanism should not be assumed for each different time domain of the hypoxic ventilatory response, and it is critical to specify a given mechanism if it is important for designing an experiment or interpreting results about the hypoxic ventilatory response. Here, we highlight recent work on the study of LTF to illustrate how multiple signaling pathways can induce the same physiological hypoxic ventilatory response.

\section{LTF - historically a serotonin-dependent pathway}

LTF has been observed in a wide variety of animals, both as increased ventilation (ventilatory LTF) or enhanced phrenic nerve activity (phrenic LTF) in awake or anesthetized animals, respectively $[2,6-9]$. Ventilatory LTF is more difficult to study experimentally and appears to depend on sleep-wakefulness state, species, and the hypoxic induction protocol; this topic has been expertly reviewed recently $[10,11]$. Recent studies show that ventilatory LTF may be the sum of plasticity in genioglossal, hypoglossal, and intercostal motor responses, in addition to phrenic responses $[2,10,12,13]$. Most of the experimental work defining neurochemical mechanisms of LTF has been done in anesthetized animal preparations and focuses on phrenic LTF. Probably the first description of LTF in the literature was the report of serotonindependent "afterdischarge" in phrenic activity in anesthetized cats in response to repeated bouts of carotid sinus nerve stimulation $[14,15]$. The hypoxic stimulus for LTF must be intermittent as it is not induced by continuous hypoxia of the same duration as the sum of the intermittent episodes [16].

Until recently, serotonin type 2 receptor $\left(5-\mathrm{HT}_{2} \mathrm{R}\right)$ activation during, but not after, intermittent hypoxia was thought to be the primary signaling mechanism for ventilatory LTF and phrenic LTF [17-19]. Experimental evidence for this includes the observations that phrenic LTF induced by intermittent hypoxia or carotid sinus nerve stimulation is prevented by $5-\mathrm{HT}_{2} \mathrm{R}$ blockade with the general 5 -HTR antagonist methysergide [20], or ketanserin, a specific $5-\mathrm{HT}_{2} \mathrm{R}$ antagonist [21-23]. The working model for the $5-\mathrm{HT}_{2}$ mechanism of LTF has been as follows (Fig. 1). First, episodic hypoxia activates serotonergic Raphe neurons in the medulla, which results in the release of the neuromodulator 5-HT near phrenic motor neurons; such 5-HT release has been measured when the carotid sinus nerve is electrically stimulated [24], and there is strong evidence for it occurring with hypoxia as well [25-29]. 5-HT then activates a variety of downstream signals that activate protein kinases to initiate new protein synthesis and enhance glutamatergic neurotransmission [22,30,31]. Presumably, this involves inserting glutamate receptors into the post-synaptic membrane and/or phosphorylating them to enhance sensitivity to pre-synaptic inputs, as described for other glutamatergic systems [32-34]. However, it has not been conclusively demonstrated that the mechanisms of LTF are explicit to synapses on respiratory motor neurons, and potential roles for changes in cellular excitability, interneurons, or glia have not been ruled out. Episodic activation of $5-\mathrm{HT}_{2}$ Rs leads to synthesis of brainderived neurotrophic factor (BDNF) in the spinal cord near the phrenic motorneurons. Evidence supporting this includes observations that a single intrathecal BDNF administration induces LTF without a hypoxic stimulus, and that blocking BDNF translation and protein synthesis with RNAi approaches abolishes hypoxia-induced LTF [30]. BDNF subsequently activates high-affinity receptor tyrosine kinases (TrkB), which in turn activate extracellular signalregulated kinases 1 and 2 (ERK1/2) [30,35,36]. ERK1/2 regulate glutamatergic receptor phosphorylation and/or density at the postsynaptic membrane in other systems [37] and presumably this results in phrenic LTF $[22,23]$.

It is interesting to note that although intermittent, but not chronic, hypoxic exposures are required to induce LTF, a single bolus injection of BDNF is sufficient to activate LTF. This raises interesting questions about the activation of LTF and how the ventilatory control system differentiates between patterns of hypoxic exposure. Presumably, the increase in BDNF with the first bout of intermittent hypoxia or the start of sustained hypoxia is not sufficient to induce LTF. However, it is not known how multiple short bouts of hypoxia increase BDNF differently to cause LTF.

Chronic intermittent hypoxia, studied by exposing animals to several hours of intermittent hypoxia per day for between 4 days to 5 weeks, increases phrenic LTF $[23,38]$. Increased phrenic LTF with chronic intermittent hypoxia involves both elevated carotid body chemoreceptor responses to a given hypoxic stimulus (sensory LTF [39]) and increased central nervous system (CNS) gain of the hypoxic ventilatory response, which is demonstrated by a potentiated phrenic nerve response to electrical stimulation of the carotid sinus nerve [23]. This effect has been reported in animals treated with intermittent hypoxia using hypoxic bouts between 15 seconds (plus 68-85 seconds of graded 
Figure I. Classic model of signaling for phrenic long-term facilitation
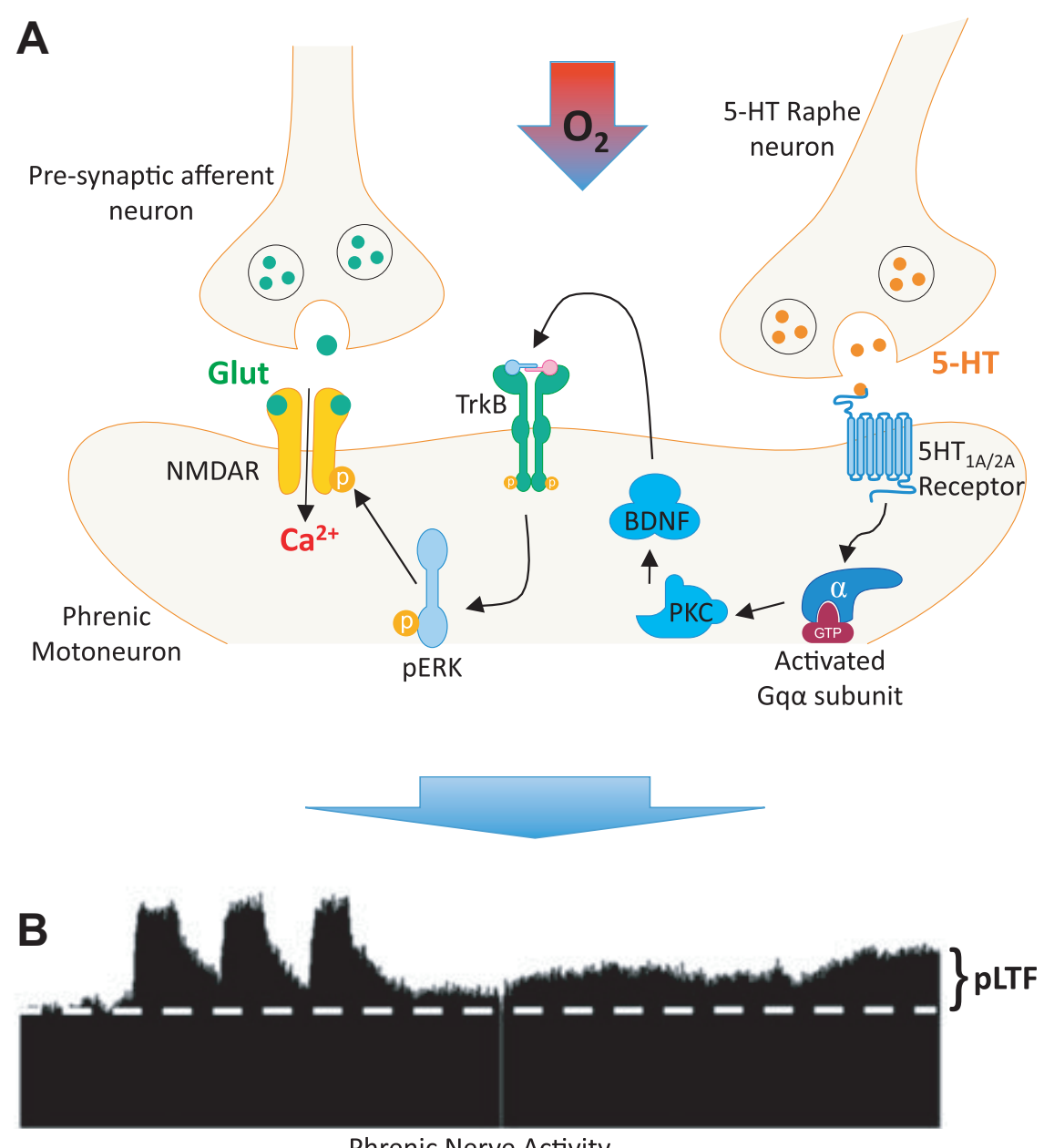

Phrenic Nerve Activity

Intermittent hypoxia increases ventilatory drive during acute hypoxia and normoxic (baseline) ventilation remains elevated for over an hour after intermittent hypoxia. (A) Carotid body stimulation by IH releases serotonin $(5-\mathrm{HT})$ from neuromodulatory Raphe neurons, which binds to 5-HT type IA and $2 \mathrm{~A}$ receptors on phrenic motorneurons. 5-HT activates $G_{q}$ protein signaling cascades to activate protein kinase $C$ (PKC) and induce the synthesis of brain-derived neurotrophic factor (BDNF). BDNF binds to tyrosine kinase receptors (TrkB) that activate phospho-extracellular signal regulated kinase (pERK). In other systems, pERK has been shown to phosphorylate glutamatergic N-methyl-D-aspartate receptors (NMDARs) in post-synaptic neurons and increase sensitivity to pre-synaptic glutamate release. (B) Physiologically, this increased sensitivity manifests as enhanced phrenic nerve activity and increased ventilation (primarily increased tidal volume). Figure $\mathrm{I}$ is modified from [44,53].

hypoxia during the change from normoxia to the target level of hypoxia) and 5 minutes long for several days, but it does not occur in response to chronic sustained hypoxia $[10,39]$. Chronic intermittent hypoxia induces new synthesis of the proteins that mediate the LTF pathway [40] and increases phrenic LTF [23,39]. Interestingly, phrenic LTF after chronic intermittent hypoxia still depends on $5-\mathrm{HT}_{2} \mathrm{Rs}$, but the increment in phrenic LTF with chronic versus acute intermittent hypoxia involves central (versus carotid body) effects of a different subtype of 5-HTR, which is sensitive to methysergide [23]. This finding provided early evidence that LTF could be regulated by multiple mechanisms (see below).

\section{LTF without serotonin}

More recent studies challenged the idea that serotonergic inputs are necessary to induce LTF. For example, activation of $\alpha 1$-adrenergic receptors can induce phrenic LTF independently of 5-HT receptors via a pathway that is mediated by protein kinase B (Akt) instead of ERKs [41,42]. Interestingly, both $\alpha 1$-adrenergic receptors and 5-HT receptors are coupled to $\mathrm{G}_{\mathrm{q}}$-proteins, a class of g-protein that is linked to the activity of phospholipase C [43], suggesting that these two types of receptor may converge on a common pathway and serve as common activators of LTF. It has been proposed that these two mechanisms form a pathway termed the "Q" Pathway (Fig. 2) [44]. 
Figure 2. New model for phrenic long-term facilitation with multiple signaling pathways

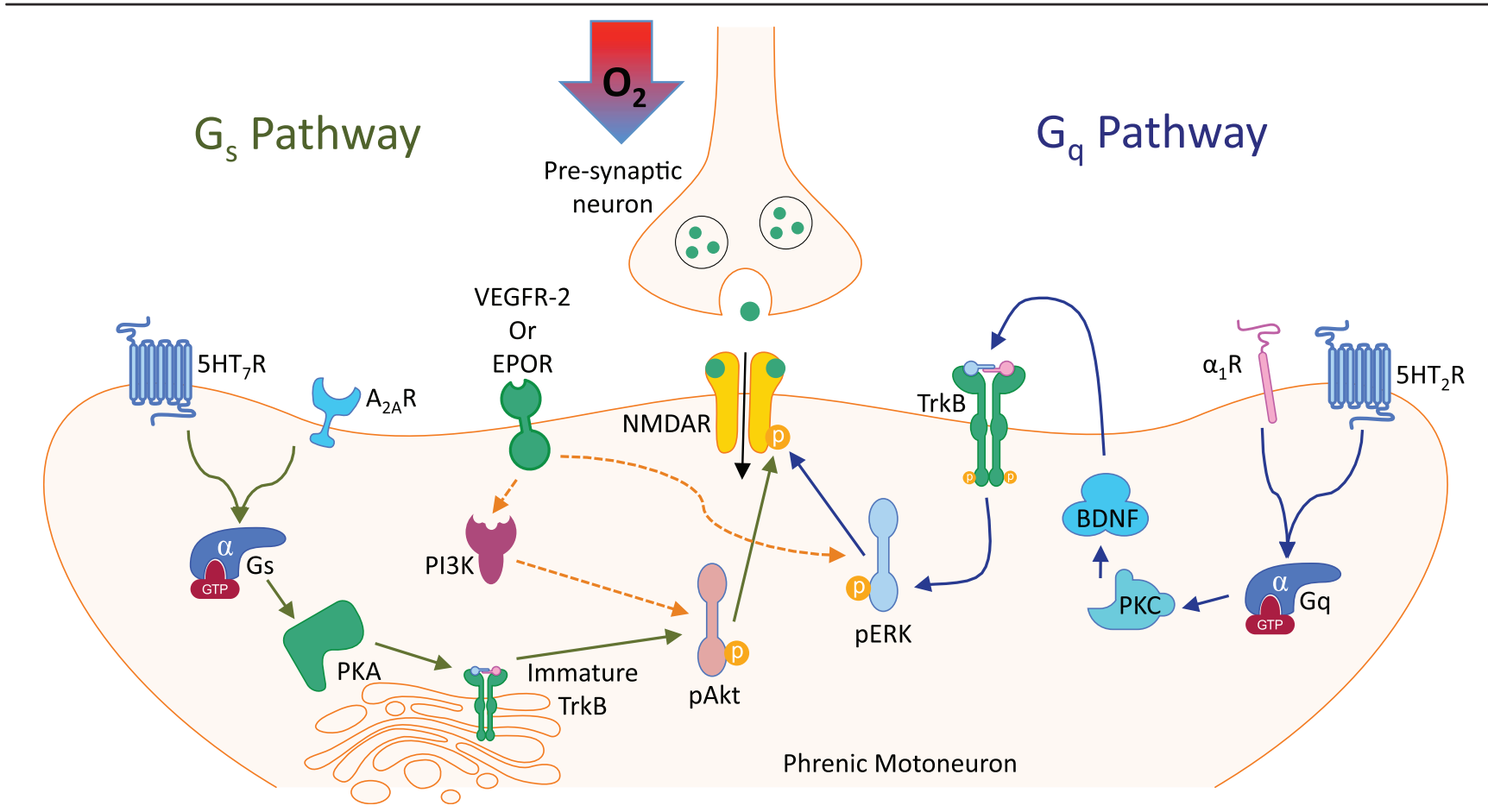

The $\mathbf{G}_{\mathbf{q}}$ pathway (blue arrows) proceeds as described in Fig. IA but can also be activated by $\alpha$ I-adrenergic receptors ( $\left.\alpha_{\mathbf{l}} \mathbf{R}\right)$ and less severe hypoxia than the $G_{s}$ pathway [47]. The $\mathbf{G}_{s}$ pathway (green arrows) can be induced by the activation of adenosine type $2 A$ receptors $\left(A_{2 A} R\right)$ or serotonin type 7 receptors $\left(5-\mathrm{HT}_{7} \mathrm{R}\right)$, which are coupled to $\mathrm{G}_{\mathrm{s}}$ proteins. $\mathrm{G}_{\mathrm{s}}$ signaling activates protein kinase $A(P K A)$, which stimulates immature TrkB to modulate phospho-protein kinase $B(p A k t)$. In other systems, this phosphorylates glutamatergic N-methyl-D-aspartate receptors (NMDARs) and increases sensitivity to pre-synaptic glutamate release. Recently, additional pathways (dashed arrows) have been described wherein vascular endothelial growth factor receptor-2 (VEGFR-2) or erythropoietin receptor (EPOR) induce LTF via phosphoinositide 3-kinase (PI3K) and pAkt, and perhaps pERK. Potential effects of reactive oxygen species on $\mathrm{G}_{\mathrm{s}}$ and $\mathrm{G}_{\mathrm{q}}$ pathway interactions are not shown. Figure 2 is modified from [44].

Recently, another signaling pathway capable of inducing phrenic LTF has been reported, and it is mediated by spinal cord adenosine type $2 \mathrm{~A}$ receptors $\left(\mathrm{A}_{2 \mathrm{~A}} \mathrm{R}\right)$ [45-47] and $5-\mathrm{HT}_{7} \mathrm{Rs}$ [45-48]. $\mathrm{A}_{2 \mathrm{~A}} \mathrm{Rs}$ signal through adenylate cyclase-coupled $\mathrm{G}_{\mathrm{s}}$ proteins, and, accordingly, this pathway has been termed the "S" pathway (Fig. 2) [44]. Support for the idea that $G_{s}$ signaling has a more general role in LTF comes from the observation that $5-\mathrm{HT}_{7} \mathrm{Rs}$, which also utilize $G_{s}$, can induce long-lasting phrenic motor facilitation [48]. It is possible that $5-\mathrm{HT}_{7} \mathrm{Rs}$ play a role in the enhanced phrenic LTF observed with chronic intermittent hypoxia (see above). Interestingly, the $\mathrm{S}$ Pathway involves activation of immature TrkB independently of BDNF synthesis and this pathway proceeds through the activation of PI3K/Akt, but does not involve ERKs [45]. The S and Q pathways are simultaneously initiated by intermittent hypoxia but they tend to limit each other, since blocking only one pathway increases phrenic LTF $[44,46]$. This interaction is typical of $\mathrm{G}_{\mathrm{s}}$ and $G_{q}$ proteins, which interfere with each other via a well-described cross-talk mechanism in other systems
[49]. This cross-talk may involve reactive oxygen species [46], which are involved in phrenic LTF and ventilatory LTF [50-54] (the effects of reactive oxygen species on LTF are beyond the scope of this brief review). The physiological significance of the dual G protein mechanisms for the hypoxic ventilatory response may relate to the recent discovery that different levels of hypoxia induce different pathways for phrenic LTF, such that more severe hypoxic episodes $\left(25-30 \mathrm{mmHg} \mathrm{Pa}_{\mathrm{O} 2}\right.$ ) preferably induce the S Pathway, whereas during moderate hypoxia (45-55 $\mathrm{mmHg}^{\mathrm{Pa}_{\mathrm{O} 2}}$ ), the Q pathway is favoured [47].

In addition to these pathways, signaling mechanisms mediated by vascular endothelial growth factor [55], and erythropoietin [56], have also recently been described, and both pathways interact with ERK and Akt signaling [44,55-58]. It remains to be seen how these mechanisms utilize components of the Q and S pathways, or if they represent entirely new signaling mechanisms that mediate phrenic LTF. 
Beyond LTF, the Q and S pathways are important modulators of a variety of respiratory and non-respiratory circuits that mediate both sensory and motor systems. For example, the $G_{s}$ pathway has been implicated in several related processes: the regulation of heart rate by sympathetic and vagal nerve $\beta$-adrenergic inputs to cardiac pacemaker cells [59]; the control of respiratory depression during rapid eye movement (REM) sleep via a mechanism involving adenylyl cyclase [60]; and the sensitivity of inhibitory glycine receptors, which play important roles in motor control, pain, and ventilation $[61,62]$. Similarly, the Q pathway has been implicated in central pattern generation of respiratory control in the brainstem of juvenile rats [63], while interactions between the Q pathway and other $G$ protein receptors mediate Purkinje cell signaling in the coordination of motor control [64]. In general, the activity of the various $G$ proteins and their interactions occur via highly conserved signaling pathways, so research in other areas will likely prove valuable for understanding of the roles of these pathways in LTF, and vice versa.

\section{Age, gender, and strain in the manifestation of LTF}

An important caveat to this research is that the majority of studies have been undertaken in young male SpragueDawley rats. Sex hormones regulate plasticity in the CNS, including those for ventilatory responses to intermittent hypoxia $[65,66]$. Research has demonstrated that the magnitude of phrenic LTF is markedly reduced in old versus young male Sprague-Dawley rats (13 vs. 3-4 months), and LTF of the hypoglossal nerve is abolished in the older population [67]. This effect has been linked to the expression of sex hormones and LTF of the phrenic and hypoglossal nerves is similarly abrogated in gonadectomised or aged male Fischer 344 rats relative to young intact animals; the decrease in hypoglossal LTF correlates with decreased expression of the sex hormones testosterone, progesterone, and oestradiol [68], and testosterone supplementation reverses the effects of gonadectomy [69], or aging [70]. Furthermore, the expression of LTF has also been shown to vary between different strains of rats, such that acute intermittent hypoxia-induced changes in 5-HT signaling, phrenic LTF, and LTF of the hypoglossal nerve are not observed in Brown Norway rats, and are more pronounced in Lewis rats than in Fischer 344 rats $[71,72]$. This indicates that genetic and epigenetic differences may also contribute to the extent to which LTF is induced by intermittent hypoxia.

\section{Conclusions}

New experiments demonstrate multiple pathways for the physiological expression of LTF of respiratory motor activity following intermittent hypoxia. Hence, a given neurochemical mechanism cannot be used to define a given time domain of the hypoxic ventilatory response. The physiological significance for different mechanisms for LTF remains to be determined and, in particular, differences in sensitivity of the $Q$ versus $S$ pathways to various patterns of intermittent hypoxia remain to be tested. Also, the idea that LTF and ventilatory acclimatization to chronic sustained hypoxia use different signaling mechanisms can be questioned; a critical argument supporting different mechanisms for these two forms of plasticity has been that the mechanism of LTF requires serotonin, while ventilatory acclimatization to hypoxia does not [2]; however, the recent discovery of serotonin-independent LTF nullifies this distinction. Finally, the clinical significance of LTF and its role in sleep-disordered breathing remains to be determined. Depending on how LTF affects individual ventilatory and upper airway muscles, loop gain, and ventilatory thresholds, LTF might stabilize or destabilize breathing with intermittent hypoxia during sleepdisordered breathing [73-75].

\section{Abbreviations}

5-HT, 5-hydroxytryptamine; $\mathrm{A}_{2 \mathrm{~A}} \mathrm{R}$, adenosine type 2 receptors; Akt, protein kinase $\mathrm{B}$; $\mathrm{BDNF}$, brain-derived neurotrophic factor; CNS, central nervous system; ERK, extracellular signal-regulated kinases; LTF, long-term facilitation; REM, rapid eye movement; TrkB, highaffinity receptor tyrosine kinases.

\section{Disclosure}

The authors declare that they have no disclosures.

\section{Acknowledgements}

This work was supported by NIH grants 2R01HL081823 and 1P01HL098053 (Frank L. Powell).

\section{References}

I. Fitzgerald RS, Lahiri S: Reflex Responses to Chemoreceptor Stimulation. Compr Physiol 201 I, I I:3 I3-362.

2. Powell FL, Milsom WK, Mitchell GS: Time domains of the hypoxic ventilatory response. Respir Physiol 1998, I I 2(2): I23-I34.

3. Mitchell GS, Johnson SM: Neuroplasticity in respiratory motor control. J Appl Physiol 2003, 94(I):358-374.

4. Eldridge BF, Millhorn DE: Oscillation, gating, and memory in the prespiratory control system. In Handbook of Physiology, section 3: The Respiratory System: Control of Breathing, part I. Edited by Cherniack NS, Widdicombe JG. vol. 2. Washington, D.C.: American Physiological Society; 1986, 93-II4.

5. Mitchell GS, Baker TL, Nanda SA, Fuller DD, Zabka AG, Hodgeman BA, Bavis RW, Mack KJ, Olson EB Jr.: Invited review: Intermittent hypoxia and respiratory plasticity. J Appl Physiol 200I, 90(6): 2466-2475.

6. Mitchell GS, Powell FL, Hopkins SR, Milsom WK: Time domains of the hypoxic ventilatory response in awake ducks: episodic and continuous hypoxia. Respir Physiol 200 I, I 24(2): I I7-I 28.

7. Morris KF, Gozal D: Persistent respiratory changes following intermittent hypoxic stimulation in cats and human beings. Respir Physiol Neurobiol 2004, I40(I): I-8.

8. Terada J, Nakamura A, Zhang W, Yanagisawa M, Kuriyama T, Fukuda Y, Kuwaki T: Ventilatory long-term facilitation in mice 
can be observed during both sleep and wake periods and depends on orexin. J Appl Physiol 2008, 104(2):499-507.

\section{FIOOOPrime}

9. Fuller DD, Bach KB, Baker TL, Kinkead R, Mitchell GS: Long term facilitation of phrenic motor output. Respir Physiol 2000, I 2 I (2-3): I35-I46.

10. Mateika JH, Sandhu KS: Experimental protocols and preparations to study respiratory long term facilitation. Respir Physiol Neurobiol 20I I, I76(I-2): I-II.

\section{FlOOOPrime \\ RECOMMENDED}

II. Mitchell GS, Terada J: Should we standardize protocols and preparations used to study respiratory plasticity? Respir Physiol Neurobiol 20I I, I77(2):93-97.

12. McKay LC, Janczewski WA, Feldman JL: Episodic hypoxia evokes long-term facilitation of genioglossus muscle activity in neonatal rats. J Physiol 2004, 557(Pt I): I3-18.

\section{FlOOOPrime} RECOMMENDED

13. Fregosi RF, Mitchell GS: Long-term facilitation of inspiratory intercostal nerve activity following carotid sinus nerve stimulation in cats. J Physiol 1994, 477(Pt 3):469-479.

\section{FlOOOPrime} RECOMMENDED

14. Millhorn DE, Eldridge FL, Waldrop TG: Prolonged stimulation of respiration by endogenous central serotonin. Respir Physiol 1980, 42(3): | $7 \mid-188$.

15. Millhorn DE, Eldridge FL, Waldrop TG: Prolonged stimulation of respiration by a new central neural mechanism. Respir Physiol 1980, $41(1): 87-103$.

\section{FlOOOPrime
RECOMMENDED}

16. Dwinell MR, Janssen PL, Bisgard GE: Lack of long-term facilitation of ventilation after exposure to hypoxia in goats. Respir Physiol 1997, 108(I): 1-9.

\section{FlOOOPrime
RECOMMENDED}

17. Baker-Herman TL, Mitchell GS: Phrenic long-term facilitation requires spinal serotonin receptor activation and protein synthesis. J Neurosci 2002, 22(14):6239-6246.

18. Fuller DD, Zabka AG, Baker TL, Mitchell GS: Phrenic long-term facilitation requires 5-HT receptor activation during but not following episodic hypoxia. J Appl Physiol 200I, 90(5):200 I-2006 discussion 2000

19. Baker TL, Fuller DD, Zabka AG, Mitchell GS: Respiratory plasticity: differential actions of continuous and episodic hypoxia and hypercapnia. Respir Physiol 200 I, I 29(I-2):25-35.

\section{FlOOOPrime \\ RECOMMENDED}

20. Bach KB, Mitchell GS: Hypoxia-induced long-term facilitation of respiratory activity is serotonin dependent. Respir Physiol 1996, I 04(2-3):25|-260.

\section{FlOOOPrime}

\section{RECOMMENDED}

21. Zhang Y, McGuire M, White DP, Ling L: Serotonin receptor subtypes involved in vagus nerve stimulation-induced phrenic long-term facilitation in rats. Neurosci Lett 2004, 363(2): I 08- I I I.

22. McGuire M, Zhang Y, White DP, Ling L: Serotonin receptor subtypes required for ventilatory long-term facilitation and its enhancement after chronic intermittent hypoxia in awake rats. Am J Physiol Regul Integr Comp Physiol 2004, 286(2): R334-34I.
23. Ling L, Fuller DD, Bach KB, Kinkead R, Olson EB Jr., Mitchell GS: Chronic intermittent hypoxia elicits serotonin-dependent plasticity in the central neural control of breathing. J Neurosci 200I, 2 I (I4):538I-5388.

\section{FlOOOPRIM
RECOMMENDED}

24. Brodin E, Linderoth B, Goiny M, Yamamoto Y, Gazelius B, Millhorn DE, Hokfelt $T$, Ungerstedt $U$ : In vivo release of serotonin in cat dorsal vagal complex and cervical ventral horn induced by electrical stimulation of the medullary raphe nuclei. Brain Res 1990, 535(2): 227-236.

\section{FlOOOPrime}

\section{RECOMMENDED}

25. Morris KF, Arata A, Shannon R, Lindsey BG: Inspiratory drive and phase duration during carotid chemoreceptor stimulation in the cat: medullary neurone correlations. J Physiol I996, 49 I (Pt I): 24I-259.

26. Richter DW, Schmidt-Garcon P, Pierrefiche O, Bischoff AM, Lalley PM: Neurotransmitters and neuromodulators controlling the hypoxic respiratory response in anaesthetized cats. J Physiol 1999, 5 I 4(Pt 2):567-578.

27. Kinkead R, Bach KB, Johnson SM, Hodgeman BA, Mitchell GS: Plasticity in respiratory motor control: intermittent hypoxia and hypercapnia activate opposing serotonergic and noradrenergic modulatory systems. Comp Biochem Physiol A Mol Integr Physiol 200I, I30(2):207-218.

28. Erickson JT, Millhorn DE: Hypoxia and electrical stimulation of the carotid sinus nerve induce Fos-like immunoreactivity within catecholaminergic and serotoninergic neurons of the rat brainstem. J Comp Neurol 1994, 348(2): I6 I-182.

29. Erickson JT, Millhorn DE: Fos-like protein is induced in neurons of the medulla oblongata after stimulation of the carotid sinus nerve in awake and anesthetized rats. Brain Res I99 I, 567(I): I I-24.

30. Baker-Herman TL, Fuller DD, Bavis RW, Zabka AG, Golder FJ Doperalski NJ, Johnson RA, Watters JJ, Mitchell GS: BDNF is necessary and sufficient for spinal respiratory plasticity following intermittent hypoxia. Nat Neurosci 2004, 7(I):48-55.

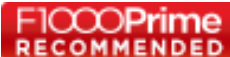

3I. Feldman JL, Mitchell GS, Nattie EE: Breathing: rhythmicity, plasticity, chemosensitivity. Annu Rev Neurosci 2003, 26:239-266.

\section{FlOOOPrime} RECOMMENDED

32. Sanchez-Perez A, Llansola M, Cauli O, Felipo V: Modulation of NMDA receptors in the cerebellum. II. Signaling pathways and physiological modulators regulating NMDA receptor function. Cerebellum 2005, 4(3): I62-I70.

33. Llansola M, Sanchez-Perez A, Cauli O, Felipo V: Modulation of NMDA receptors in the cerebellum. I. Properties of the NMDA receptor that modulate its function. Cerebellum 2005, 4(3): I 54- I6 I.

34. Lisman J, Raghavachari S: A unified model of the presynaptic and postsynaptic changes during LTP at CAI synapses. SCi STKE 2006, 2006(356):rell.

35. Wilkerson JE, Mitchell GS: Daily intermittent hypoxia augments spinal BDNF levels, ERK phosphorylation and respiratory long-term facilitation. Exp Neurol 2009, 2 I 7(I): | |6-I23.

\section{FlOOOPrime \\ RECOMMENDED}

36. Kishino A, Nakayama C: Enhancement of BDNF and activatedERK immunoreactivity in spinal motor neurons after peripheral administration of BDNF. Brain Res 2003, 964(I):56-66.

\section{FlOOOPrime}

\section{RECOMMENDED}

37. Roskoski R Jr.: ERKI/2 MAP kinases: structure, function, and regulation. Pharmacol Res 2012, 66(2): I05-143. 
38. O'Halloran KD, McGuire M, O'Hare T, Bradford A: Chronic intermittent asphyxia impairs rat upper airway muscle responses to acute hypoxia and asphyxia. Chest 2002, I22(I): 269-275.

\section{FlOOOPrime} RECOMMENDED

39. Peng YJ, Prabhakar NR: Effect of two paradigms of chronic intermittent hypoxia on carotid body sensory activity. J Appl Physiol 2004, 96(3): I236-1242 discussion I 196.

\section{FlOOOPrime \\ RECOMMENDED}

40. Wei XY, Liu JP, Zhao CH, Ju G, Wong-Riley MT, Liu YY: Expressions of 5-HT/5-HT(2A) receptors and phospho-protein kinase C theta in the pre-Botzinger complex in normal and chronic intermittent hypoxic rats. Neuroscience 2010, 168(I):6I-73.

\section{FlOOOPrime
RECOMMENDED}

4I. Neverova NV, Saywell SA, Nashold LJ, Mitchell GS, Feldman JL: Episodic stimulation of alphal-adrenoreceptors induces protein kinase C-dependent persistent changes in motoneuronal excitability. J Neurosci 2007, 27(I6):4435-4442.

\section{FlOOOPrime}

RECOMMENDED

42. Hoffman MS, Nichols NL, Macfarlane PM, Mitchell GS: Phrenic longterm facilitation after acute intermittent hypoxia requires spinal ERK activation but not TrkB synthesis. J Appl Physiol 2012, II3(8): I I84-I I 93.

FlOOOPrime

\section{RECOMMENDED}

43. Bockaert J, Claeysen S, Becamel C, Dumuis A, Marin P: Neuronal 5-HT metabotropic receptors: fine-tuning of their structure, signaling, and roles in synaptic modulation. Cell Tissue Res 2006, 326(2):553-572.

44. Dale-Nagle EA, Hoffman MS, MacFarlane PM, Mitchell GS: Multiple pathways to long-lasting phrenic motor facilitation. Adv Exp Med Biol 2010, 669:225-230.

\section{FlOOOPRime}

45. Golder FJ, Ranganathan L, Satriotomo I, Hoffman M, Lovett-Barr MR, Watters ]J, Baker-Herman TL, Mitchell GS: Spinal adenosine A2a receptor activation elicits long-lasting phrenic motor facilitation. J Neurosci 2008, 28(9):2033-2042.

\section{FlOOOPrime}

RECOMMENDED

46. Hoffman MS, Golder FJ, Mahamed S, Mitchell GS: Spinal adenosine A2 (A) receptor inhibition enhances phrenic long term facilitation following acute intermittent hypoxia. J Physiol 2010, 588(Pt I): 255-266.

\section{FlOOOPrime}

\section{RECOMMENDED}

47. Nichols NL, Dale EA, Mitchell GS: Severe acute intermittent hypoxia elicits phrenic long-term facilitation by a novel adenosinedependent mechanism. J Appl Physiol 2012, II 2(10): 1678-I688.

\section{FlOOOPrime
RECOMMENDED}

48. Hoffman MS, Mitchell GS: Spinal 5-HT7 receptor activation induces long-lasting phrenic motor facilitation. J Physiol $201 \mathrm{I}$, 589(Pt 6): I397-| 407

\section{FlOOOPRime}

49. Roy AA, Nunn C, Ming H, Zou MX, Penninger J, Kirshenbaum LA, Dixon SJ, Chidiac P: Up-regulation of endogenous RGS2 mediates cross-desensitization between Gs and Gq signaling in osteoblasts. J Biol Chem 2006, 28 I (43):32684-32693.

50. MacFarlane PM, Wilkerson JE, Lovett-Barr MR, Mitchell GS: Reactive oxygen species and respiratory plasticity following intermittent hypoxia. Respir Physiol Neurobiol 2008, I64(I-2):263-27I.
5I. MacFarlane PM, Mitchell GS: Respiratory long-term facilitation following intermittent hypoxia requires reactive oxygen species formation. Neuroscience 2008, I52(I):189-197.

52. MacFarlane PM, Mitchell GS: Episodic spinal serotonin receptor activation elicits long-lasting phrenic motor facilitation by an NADPH oxidase-dependent mechanism. J Physiol 2009, 587(Pt 22): 5469-548I.

53. MacFarlane PM, Satriotomo I, Windelborn JA, Mitchell GS: NADPH oxidase activity is necessary for acute intermittent hypoxiainduced phrenic long-term facilitation. J Physiol 2009, 587(Pt 9): 1931-1942.

54. Lee DS, Badr MS, Mateika JH: Progressive augmentation and ventilatory long-term facilitation are enhanced in sleep apnoea patients and are mitigated by antioxidant administration. J Physiol 2009, 587(Pt 22):545 I-5467.

\section{FlOOOPrime \\ RECOMMENDED}

55. Dale-Nagle EA, Satriotomo I, Mitchell GS: Spinal vascular endothelial growth factor induces phrenic motor facilitation via extracellular signal-regulated kinase and Akt signaling. J Neurosci 20I I, 3 I (2I):7682-7690.

\section{FlOOOPrime
RECOMMENDED}

56. Dale EA, Satriotomo I, Mitchell GS: Cervical spinal erythropoietin induces phrenic motor facilitation via extracellular signalregulated protein kinase and Akt signaling. J Neurosci 2012, 32(17):5973-5983.

\section{FlOOOPrime}

RECOMMENDED

57. Dale EA, Mitchell GS: Spinal vascular endothelial growth factor (VEGF) and erythropoietin (EPO) induced phrenic motor facilitation after repetitive acute intermittent hypoxia. Respir Physiol Neurobiol 2013, 185(3):48I-488.

58. Satriotomo I, Dale EA, Dahlberg JM, Mitchell GS: Repetitive acute intermittent hypoxia increases expression of proteins associated with plasticity in the phrenic motor nucleus. Exp Neurol 2012, 237(I):103-115.

59. Yatani A, Okabe K, Codina J, Birnbaumer L, Brown AM: Heart rate regulation by $\mathbf{G}$ proteins acting on the cardiac pacemaker channel. Science 1990, 249(4973): I 163-I I66.

60. Shuman SL, Capece ML, Baghdoyan HA, Lydic R: Pertussis toxinsensitive $\mathbf{G}$ proteins mediate carbachol-induced REM sleep and respiratory depression. Am J Physiol 1995, 269(2 Pt 2):R308-3 17.

61. Yevenes GE, Moraga-Cid G, Romo X, Aguayo LG: Activated G protein alpha $s$ subunits increase the ethanol sensitivity of human glycine receptors. J Pharmacol Exp Ther 20I I, 339(2):386-393.

62. Yevenes GE, Peoples RW, Tapia JC, Parodi J, Soto X, Olate J, Aguayo LG: Modulation of glycine-activated ion channel function by G-protein betagamma subunits. Nat Neurosci 2003, 6(8):819-824. FlOOOPrime RECOMMENDED

63. Niebert M, Vogelgesang S, Koch UR, Bischoff AM, Kron M, Bock N, Manzke T: Expression and function of serotonin $2 A$ and $2 B$ receptors in the mammalian respiratory network. PLoS One 201 I, 6(7):e21395.

64. Hartmann J, Blum R, Kovalchuk $Y$, Adelsberger H, Kuner R, Durand GM, Miyata M, Kano M, Offermanns S, Konnerth A: Distinct roles of Galpha(q) and Galphal I for Purkinje cell signaling and motor behavior. J Neurosci 2004, 24(22):51 I9-5130.

65. Behan M, Zabka AG, Mitchell GS: Age and gender effects on serotonin-dependent plasticity in respiratory motor control. Respir Physiol Neurobiol 2002, I 3 I (I-2):65-77.

66. Tatsumi K, Hannhart B, Moore LG: Influences of sex steroids on ventilation and ventilatory control. In Regulation of Breathing. Edited by Dempsey JA, Pack AlJ. New York: Marcel Dekker; 1995. 
67. Zabka AG, Behan M, Mitchell GS: Long term facilitation of respiratory motor output decreases with age in male rats. J Physiol 200I, 53 I (Pt 2):509-5I4.

\section{FlOOOPrime}

\section{RECOMMENDED}

68. Zabka AG, Mitchell GS, Behan M: Ageing and gonadectomy have similar effects on hypoglossal long-term facilitation in male Fischer rats. J Physiol 2005, 563(Pt 2):557-568.

\section{FlOOOPrime}

\section{RECOMMENDED}

69. Zabka AG, Mitchell GS, Behan M: Conversion from testosterone to oestradiol is required to modulate respiratory long-term facilitation in male rats. J Physiol 2006, 576(Pt 3):903-912.

70. Nelson NR, Bird IM, Behan M: Testosterone restores respiratory long term facilitation in old male rats by an aromatasedependent mechanism. J Physiol 20I I, 589 (Pt 2):409-42I.

\section{FlOOOPrime}

7I. Baker-Herman TL, Bavis RW, Dahlberg JM, Mitchell AZ, Wilkerson JE, Golder FJ, Macfarlane PM, Watters JJ, Behan M, Mitchell GS: Differential expression of respiratory long-term facilitation among inbred rat strains. Respir Physiol Neurobiol 2010, 170(3): 260-267.

72. Golder FJ, Zabka AG, Bavis RW, Baker-Herman T, Fuller DD, Mitchell GS: Differences in time-dependent hypoxic phrenic responses among inbred rat strains. J Appl Physiol 2005, 98(3): 838-844.

73. Mahamed S, Mitchell GS: Respiratory long-term facilitation: too much or too little of a good thing? Adv Exp Med Biol 2008, 605:224-227.

74. Edwards BA, Sands SA, Eckert DJ, White DP, Butler JP, Owens RL, Malhotra A, Wellman A: Acetazolamide improves loop gain but not the other physiological traits causing obstructive sleep apnoea. J Physiol 2012, 590(Pt 5): I199-1211.

75. Owens $\mathrm{R}$, Wellman A, Malhotra A: The chicken-or-egg debate in OSA Pathogenesis: Commentary on Loewen et al., Sleep 2009, 32:1355-1365. Sleep 2009, 32: |255-56. 